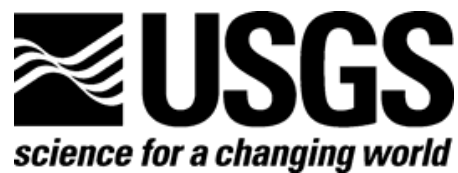

In cooperation with the National Park Service

\title{
Coastal Vulnerability Assessment of Gulf Islands National Seashore (GUIS) to Sea-Level Rise
}

By Elizabeth A. Pendleton, Erika S. Hammar-Klose, E. Robert Thieler, S. Jeffress Williams

Open-File Report 03-108

U.S. Department of the Interior

U.S. Geological Survey 


\section{U.S. Department of the Interior \\ Gail A. Norton, Secretary}

\section{U.S. Geological Survey \\ Charles G. Groat, Director}

\section{U.S. Geological Survey, Reston, Virginia}

For product and ordering information:

World Wide Web: http://Www.usgs.gov/pubprod

Telephone: 1-888-ASK-USGS

For more information on the USGS - the Federal source for science about the Earth, its natural and living resources, natural hazards, and the environment:

World Wide Web: http://www.usgs.gov

Telephone: 1-888-ASK-USGS

\section{For Additional Information:}

See the National Park Unit Coastal Vulnerability study at http://woodshole.er.usgs.gov/project-pages/nps-cvi/, the National Coastal Vulnerability study at http://woodshole.er.usgs.gov/project-pages/cvi/, or view the USGS online fact sheet for this project in PDF format at http://pubs.usgs.gov/fs/fs095-02/. To visit the Gulf Islands National Seashore (GUIS) go to http://www.nps.gov/guis/.

Contact:

E. Robert Thieler and S. Jeffress Williams and Elizabeth A. Pendleton

U.S. Geological Survey

384 Woods Hole Road

Woods Hole, MA 02543

E-mail: rthieler@usgs.gov, jwilliams@usgs.gov, ependleton@usgs.gov

Telephone: 508-457-2200 or 508-548-8700

Rebecca Beavers

National Park Service

Natural Resource Program Center

Geologic Resources Division

P.0. Box 25287

Denver, CO 80225-0287

E-mail: Rebecca_Beavers@nps.gov

Telephone: $303-987-6945$

Suggested citation:

Pendleton, E.A., Hammer-Klose,E.S., Thieler, E.R., Williams, S.J. , 2004, Coastal Vulnerability Assessment of Gulf Islands National Seashore (GUIS) to Sea Level Rise, U.S. Geological Survey Open-File Report 03-108, 18 p. http://pubs.usgs.gov/of/2003/of03-108/.

Any use of trade, product, or firm names is for descriptive purposes only and does not imply endorsement by the U.S. Government.

Although this report is in the public domain, permission must be secured from the individual copyright owners to reproduce any copyrighted material contained within this report. 


\section{Contents}

Abstract

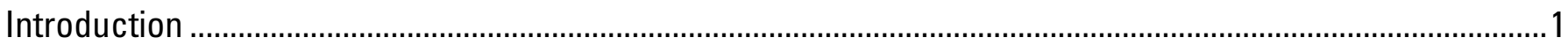

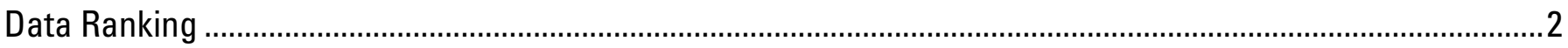

Coastal Geology of Gulf Islands National Seashore ……….........................................................................

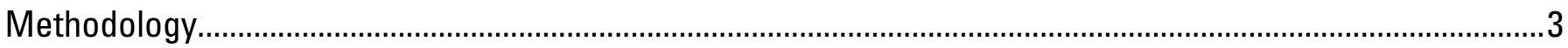

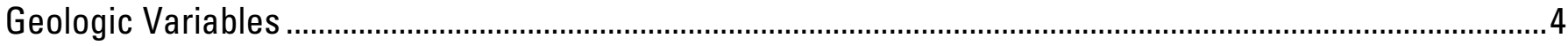

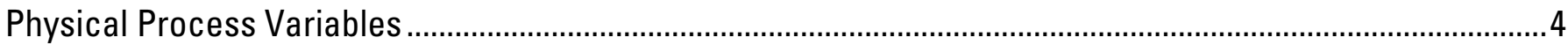

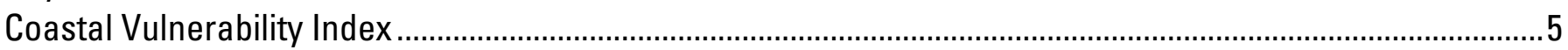

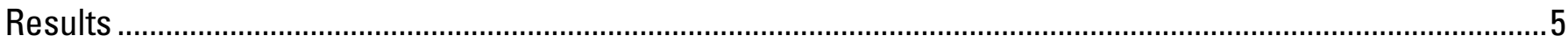

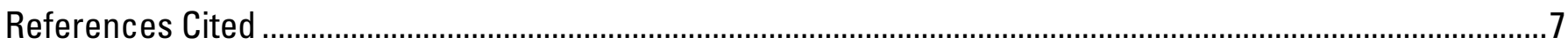

\section{Figures}

1. Location of Gulf Isalnds National Seashore. (A) Gulf Islands of Mississippi, and

(B) Gulf Islands of Florida.

2. (A) Shorline gird for Missisippi Islands, and (B) Shoreline grid fro Florida Islands ..................................... 10

3. Dominant geomorphology of Santa Rosa Island (5-very high vulnerability), here elevation is low from the Gulf (right) to Pensacola Bay (left)

4.West Ship Island looking east from Civil War era Fort Massachusetts. The geomorphology is characterized as a low elevation overwashed barrier island (5 - very high vulnerability)

5. (A) Langdon Battery near Fort Pickens appears to set on top of a large dune, however the elevation is artificial from old gun emplacements. $(B)$ view from the top of Langdon Battery

6. Dune ridge (4- high vulnerability) adjacent to washover (5- very high vulnerability) on Santa Rosa Island

7. Historic Shoreline positions for A) Cat Island, B) East and West Ship Island, C) Horn Island, D) Petit Bois Island, E) Perdido Key, and E) Western Santa Rosa Island

8. Regional coastal slope cross-section of $(A)$ Horn Island (5 - very high vulnerability). (B) Santa

Rosa Island (3 - moderate to 2 - low vulnerability). The low vulnerability portion of Santa Rosa is shown in the profile.

9. Relative Coastal Vulnerability for Gulf Islands National Seashore $(A)$ in Mississippi and $(B)$ in Florida. The innermost color bar is the relative coastal vulnerability index (CVI). The remaining color bars are separated into the geologic variables (1-3) and physical process variables (4-6). The very high vulnerability shoreline is generally along the eastern Mississippi islands. High vulnerability shoreline is concentrated around areas with a shoreline change rate between $+/-1$-meter. Moderate vulnerability shoreline is primarily on Perdido Key and Santa Rosa Island, and the low vulnerability portion of the shore lies along the eastern end of Santa Rosa Island.

10. Percentage of GUIS shoreline in each CVI vulnerability category 
11. 4.1 million cubic meters of nourishment sand were placed on Perdido Key in 1989 which influenced the rate of shoreline erosion. Prior to 1989 (black line) the calculated rate of erosion on the eastern end of Perdido Key was approximately $0.5 \mathrm{~m} / \mathrm{yr}$ greater than after 1989 (red line).

12. (A) Ft. Massachusetts in 2001 before renourishment. (B) Ft. Massachusetts in fall 2003 following beach renourishment in the spring (photos provided by Linda York)

\section{Tables}

1. Ranges for Vulnerability Ranking of Variables on the Atlantic Coast.............................................................17






\title{
Coastal Vulnerability Assessment of Gulf Islands National Seashore (GUIS) to Sea-Level Rise
}

\author{
By Elizabeth A. Pendleton, Erika S. Hammar-Klose, E. Robert Thieler, S. Jeffress Williams
}

U.S. Geological Survey Open-File Report 03-108

\begin{abstract}
A coastal vulnerability index (CVI) was used to map the relative vulnerability of the coast to future sea-level rise within Gulf Islands National Seashore (GUIS) in Mississippi and Florida. The CVI ranks the following in terms of their physical contribution to sea-level rise-related coastal change: geomorphology, regional coastal slope, rate of relative sea-level rise, shoreline change rates, mean tidal range and mean wave height. The rankings for each variable were combined and an index value calculated for 1-minute grid cells covering the park. The CVI highlights those regions where the physical effects of sea-level rise might be the greatest. This approach combines the coastal system's susceptibility to change with its natural ability to adapt to changing environmental conditions, yielding a quantitative, although relative, measure of the park's natural vulnerability to the effects of sea-level rise. The Gulf Islands in Mississippi and Florida consist of stable and washover dominated portions of barrier beach backed by wetland and marsh. The areas likely to be most vulnerable to sea-level rise are those with the highest occurrence of overwash, the highest rates of shoreline change, the gentlest regional coastal slope, and the highest rates of relative sealevel rise. The CVI provides an objective technique for evaluation and long-term planning by scientists and park managers.
\end{abstract}

\section{Introduction}

The National Park Service (NPS) is responsible for managing nearly $12,000 \mathrm{~km}$ (7,500 miles) of shoreline along oceans and lakes. In 2001, the U.S. Geological Survey (USGS), in partnership with the NPS Geologic Resources Division, began conducting hazard assessments of future sea-level change by creating maps to assist NPS in managing its valuable coastal resources. This report presents the results of a vulnerability assessment for Gulf Islands National Seashore (GUIS), highlighting areas that are likely to be most affected by future sea-level rise.

Global sea level has risen approximately 18 centimeters ( 7.1 inches) in the past century (Douglas, 1997). Climate models predict an additional rise of $48 \mathrm{~cm}$ (18.9 in.) by 2100 (IPCC, 2001), which is more than double the rate of rise for the 20th century. Potential coastal impacts of sea-level rise include shoreline erosion, saltwater intrusion into groundwater aquifers, inundation of wetlands and estuaries, and threats to cultural and historic resources as well as infrastructure. Predicted accelerated global sea-level rise has generated a need in coastal geology to determine the response 
of a coastline to sea-level rise. However, an accurate and quantitative approach to predicting coastal change is difficult to establish. Even the kinds of data necessary to make shoreline response predictions are the subject of scientific debate. A number of predictive approaches have been proposed (National Research Council, 1990), including: 1) extrapolation of historical data (e.g., coastal erosion rates), 2) static inundation modeling, 3) application of a simple geometric model (e.g., the Bruun Rule), 4) application of a sediment dynamics/budget model, or 5) Monte Carlo (probabilistic) simulation based on parameterized physical forcing variables. However, each of these approaches has inadequacies or can be invalid for certain applications (National Research Council, 1990). Additionally, shoreline response to sea-level change is further complicated by human modification of the natural coast such as beach nourishment projects, and engineered structures such as seawalls, revetments, groins, and jetties. Understanding how a natural or modified coast will respond to sea-level change is essential to preserving vulnerable coastal resources.

The primary challenge in predicting shoreline response to sea-level rise is quantifying the important variables that contribute to coastal evolution in a given area. In order to address the multi-faceted task of predicting sea-level rise impact, the USGS has implemented a methodology to identify areas that may be most vulnerable to future sea-level rise (see Hammar-Klose and Thieler, 2001). This technique focuses on six variables which strongly influence coastal evolution.

1) Geomorphology

2) Shoreline change rate

3) Coastal slope

4) Relative sea-level change

5) Mean significant wave height

6) Mean tidal range

These variables can be divided into two groups: 1) geologic variables and 2) physical process variables. The geologic variables are geomorphology, historic shoreline change rate, and coastal slope; they account for a shoreline's relative resistance to erosion, long-term erosion/accretion trend, and its susceptibility to flooding, respectively. The physical process variables include significant wave height, tidal range, and sea-level, all of which contribute to the inundation hazards of a particular section of coastline over time scales from hours to centuries. A relatively simple vulnerability ranking system (Table 1) allows the six variables to be incorporated into an equation that produces a coastal vulnerability index (CVI). The CVI can be used by scientists and park managers to evaluate the likelihood that physical change may occur along a shoreline as sea-level continues to rise. Additionally, NPS staff will be able to incorporate information provided by this vulnerability assessment technique into General Management Plans.

\section{Data Ranking}

Table 1 shows the six variables described in the Introduction, which include both quantitative and qualitative information. Actual variable values are assigned a vulnerability ranking based on value ranges, whereas the non-numerical geomorphology variable is ranked qualitatively according to the relative resistance of a given landform to erosion. Shorelines with erosion/accretion rates between 1.0 and $+1.0 \mathrm{~m} / \mathrm{yr}$ are ranked as moderate. Increasingly higher erosion or accretion rates are ranked as correspondingly higher or lower vulnerability. Regional coastal slopes range from very high risk, 
$<0.3$ percent to very low risk at values $>1.2$ percent. The rate of relative sea-level change is ranked using the modern rate of eustatic rise $(1.8 \mathrm{~mm} / \mathrm{yr})$ as very low vulnerability. Since this is a global or "background" rate common to all shorelines, the sea-level rise ranking reflects primarily local to regional isostatic or tectonic adjustment. Mean wave height rankings range from very low $(<0.55$ $\mathrm{m})$ to very high $(>1.25 \mathrm{~m})$. Tidal range is ranked such that microtidal $(<1 \mathrm{~m})$ coasts are very high vulnerability and macrotidal $(>6 \mathrm{~m})$ coasts are very low vulnerability.

\section{Coastal Geology of Gulf Islands National Seashore}

The Gulf Islands National Seashore (GUIS) lies along the Mississippi and northwestern Florida coast (fig. 1). The Gulf Islands consist of seven barriers, five in Mississippi (Cat Island, East and West Ship Island, Horn Island, and Petit Bois Island) and two in Florida (Perdido Key and Santa Rosa Island) making it the nation's largest national seashore, spanning over 150 miles (240 $\mathrm{km}$ ) of the Gulf of Mexico. The Mississippi islands lie 7 to 15 miles (11-24 km) off the mainland coast separating Mississippi Sound from the Gulf of Mexico, and are only accessible by boat. Civil War-Era Fort Massachusetts is located on West Ship Island and is a primary cultural resource preservation concern. The barriers of the National Seashore in Florida lie much closer to the mainland and are accessible by car. The Gulf Islands in Florida have historically been more stable than their Mississippi counterpart with respect to shoreline position. However, during Hurricane Frederic in 1979 the entire national seashore on Perdido Key was overwashed and flooded, and more than $90 \%$ of Santa Rosa Island was submerged as a result of the 12-14 $\mathrm{ft}(\sim 4 \mathrm{~m})$ storm surge (Doyle and others, 1984). Again, in 1995 Santa Rosa Island was almost entirely overwashed by Hurricane Opal which made landfall just east of Pensacola Beach. Opal removed dunes as high as 5 meters, leaving Santa Rosa Island more susceptible to future storms and erosion.

\section{Methodology}

In order to develop a database for a park-wide assessment of coastal vulnerability, data for each of the six variables mentioned above were gathered from state and federal agencies (Table 2). The database is based on that used by Thieler and Hammar-Klose (1999) and loosely follows an earlier database developed by Gornitz and White (1992). A comparable assessment of the sensitivity of the Canadian coast to sea-level rise is presented by Shaw and others. (1998).

The database was constructed using a 1:70,000 shoreline for the Gulf Islands that was produced from the medium resolution digital vector U.S. shoreline provided by the Strategic Environmental Assessments (SEA) Division of NOAA's Office of Ocean Resources Conservation and Assessment (ORCA) (spo.nos.noaa.gov/projects/shoreline/shoreline.html). Data for each of the six variables (geomorphology, shoreline change, coastal slope, relative sea-level rise, significant wave height, and tidal range) were added to the shoreline attribute table using a 1-minute (approximately $1.5 \mathrm{~km}$ ) grid (Figure 2). Next the data were assigned a relative vulnerability value from 1-5 (1 is very low vulnerability, 5 is very high vulnerability) based on the potential magnitude of its contribution to physical changes on the coast as sea level rises (Table 1). 


\section{Geologic Variables}

The geomorphology variable expresses the relative erodibility of different landform types (Table 1). These data were derived from 1-meter resolution digital orthophotos (Table 2). In addition, field visits were made within the park to ground-truth the geomorphologic classification. The Gulf Islands consist almost entirely of low elevation barrier islands with numerous washovers (5- very high vulnerability) (figs. 3 and 4). However, there are locations on East Ship Island, Petit Bois Island and Santa Rosa Island where the dune ridge is mature, these locations are given a slightly lower vulnerability ranking (4- high vulnerability) (Figure 5 and 6).

Shoreline erosion and accretion rates for GUIS were calculated from existing shoreline data provided by the USGS. Four shorelines from 1855-2001 were digitized. Shoreline rates of change $(\mathrm{m} / \mathrm{yr})$ were calculated at $20 \mathrm{~m}$ intervals (transects) along the coast using Digital Shoreline Analysis System (DSAS) software (http://woodshole.er.usgs.gov/project-pages/dsas/) to derive the rate of shoreline change over time. The rates for each transect within a 1-minute grid cell were averaged to determine the shoreline change value used here (fig.7A-E). Shoreline change rates in Mississippi are much more variable (very low to very high) than in Florida (mostly moderate vulnerability).

The determination of regional coastal slope identifies the relative vulnerability of inundation and the potential rapidity of shoreline retreat because low-sloping coastal regions are thought to retreat faster than steeper regions (Pilkey and Davis, 1987). The regional slope of the coastal zone was calculated from a grid of topographic and bathymetric elevations extending landward and seaward of the shoreline. For GUIS, elevation data were obtained from the National Geophysical Data Center (NGDC) as gridded topographic and bathymetric elevations at 0.1 meter resolution for 3 arc-second $(\sim 90 \mathrm{~m})$ grid cells. Coastal slope was calculated for a $10 \mathrm{~km}(6.2 \mathrm{miles})$ radius (landward and seaward of the barrier) and then resampled to 1-minute resolution (fig. 2). The coastal slope for the Gulf Islands in Mississippi was shallower (0.14-0.27\%) than the coastal slope in Florida (0.624-1.032\%) (fig. 8A-B).

\section{Physical Process Variables}

The relative sea-level change variable is derived from the increase or decrease in annual mean water elevation over time as measured at tide gauge stations along the coast. The rate of sea-level rise at Pensacola $(2.14+/-0.15 \mathrm{~mm} / \mathrm{yr})$ was used for Santa Rosa and Perdido Key. The Dauphin Island station was used for the Mississippi islands, which recorded a sea-level rise rate of $2.93+/-$ $0.59 \mathrm{~mm} / \mathrm{yr}$ (Zervas, 2001). The sea-level rise variable inherently includes both eustatic sea-level rise as well as regional sea-level rise due to isostatic and tectonic adjustments. Relative sea-level change data are a historical record, and thus only portray the recent sea-level trend (50 - 150 years).

Mean significant wave height is used here as a proxy for wave energy which drives the coastal sediment budget. Wave energy is directly related to the square of wave height:

$$
E=1 / 8 \rho g H^{2}
$$

where $E$ is energy density, $H$ is wave height, $\rho$ is water density and $g$ is acceleration due to gravity. Thus, the ability to mobilize and transport coastal sediments is a function of wave height squared. 
In this report, we use hindcast nearshore mean significant wave height data for the period 1976-95 obtained from the U.S. Army Corps of Engineers Wave Information Study (WIS) (see references in Hubertz and others, 1996). The model wave heights were compared to historical measured wave height data obtained from the NOAA National Data Buoy Center to ensure that model values are representative of the study area. For GUIS mean significant wave heights range from $0.60 \mathrm{~m}$ (if Florida) to $0.70 \mathrm{~m}$ (in Mississippi). These wave heights are considered low vulnerability (Table 1).

Tide range is linked to both episodic and permanent inundation hazards. Tide range data were obtained from the National Ocean Service (NOS) for four ocean tide stations along the Gulf Islands National Seashore; the values were contoured along the park shoreline and mapped to the 1-minute grid. All of GUIS is microtidal, therefore classified as very high vulnerability.

\section{Coastal Vulnerability Index}

The coastal vulnerability index (CVI) presented here is the same as that used in Thieler and Hammar-Klose (1999) and is similar to that used in Gornitz and others (1994), as well as to the sensitivity index employed by Shaw and others (1998). The CVI allows the six variables to be related in a quantifiable manner that expresses the relative vulnerability of the coast to physical changes due to future sea-level rise. This method yields numerical data that cannot be equated directly with particular physical effects. It does, however, highlight areas where the various effects of sea-level rise may be the greatest. Once each section of coastline is assigned a vulnerability value for each specific data variable, the coastal vulnerability index (CVI) is calculated as the square root of the product of the ranked variables divided by the total number of variables;

$$
\mathrm{CVI}=\sqrt{\frac{(a * b * c * d * e * f)}{6}}
$$

where, $a=$ geomorphology, $b=$ shoreline erosion/accretion rate, $c=$ coastal slope, $d=$ relative sealevel rise rate, $e=$ mean wave height, and $f=$ mean tide range. The CVI values reported here apply specifically to Gulf Islands National Seashore. Thus, absolute CVI values given for other coasts and parks are not directly comparable to the data presented here. To compare different coastal parks, the national-scale studies should be used (Thieler and Hammar-Klose, 1999, 2000a,b). In addition to the CVI values, the data ranges are also subdivided using values different from other studies so that the values used here reflect only the relative vulnerability along this coast. We feel this approach best describes and highlights the vulnerability specific to each park.

\section{Results}

The calculated CVI values for GUIS range from 10.33 - 25.0. The mean CVI value is 16.22; the mode and median are 14.14. The standard deviation is 4.39 . The 25 th, 50th, and 75 th percentiles are 13 . $0,15.00$, and 22.0, respectively.

Figure 9A-B shows a map of the coastal vulnerability index for the Gulf Islands National Seashore. The CVI scores are divided into low, moderate, high, and very high vulnerability categories based on the quartile ranges and visual inspection of the data. CVI values below 13.0 are assigned to the 
low vulnerability category. Values from 13.0 to 15.0 are considered moderate vulnerability. High vulnerability values lie between 15.1 and 22.0. CVI values above 22.0 are classified as very high vulnerability. Figure 10 shows the percentage of GUIS shoreline in each vulnerability category. Approximately 90 miles $(145 \mathrm{~km})$ of shoreline is evaluated in the study area. Of this total, 24 percent of the mapped shoreline is classified as being at very high vulnerability due to future sealevel rise. Eighteen percent is classified as high vulnerability, 36 percent as moderate vulnerability, and 21 percent as low vulnerability.

\section{Discussion}

Calculated CVI values suggest that the Gulf Islands in Mississippi may be at a greater vulnerability to predicted sea-level rise than the Gulf Islands of Florida (fig. 9A-B). The physical process variables are constant over the extent of the park with the exception of relative sea-level rise, where the Mississippi islands are experiencing a slightly higher rate of relative sea-level rise (fig. 9AB). The sea-level vulnerability increases from low, measured at Pensacola, to moderate based on the Dauphin Island station.

For the Gulf Islands, the geologic variables are most important in controlling the difference in vulnerability between the two sections of shoreline. The GUIS shoreline is relatively uniform, consisting of low elevation washover-dominated barriers with small sections of slightly lower vulnerability dune ridges. The geologic variability along the national seashore is most apparent in the shoreline change and coastal slope variables. Calculated shoreline change rates from 1855-2001 are much higher for the Mississippi islands. The strong westward longshore transport system produces very high erosion rates on the east end of the barriers and decreasing erosion to the west. The shoreline change data for Santa Rosa and Perdido Key over the last 150 years suggest that these shorelines are relatively stable (fig. 7 D-E). Regional coastal slope vulnerability changes significantly from Mississippi to Florida as well. The Mississippi barriers are backed by a shallow wide bay (Mississippi Sound) and the shoreface slopes very gently (fig. $8 \mathrm{~A}$ ). In contrast, Florida has a steeper sloping shoreface and the island's backbarrier lagoon is narrow and quickly approaches higher elevation mainland (fig. 8 B).

Within the Gulf Islands National Seashore, the Mississippi barriers islands may be at the highest vulnerability to sea-level rise. Areas of moderate to low vulnerability are mostly concentrated along Santa Rosa Island and Perdido Key in Florida, however, there are a few low vulnerability areas in Mississippi where rates of shoreline accretion are high. It is important to mention that CVI results for Perdido Key were influenced by a large nourishment project in 1989-1990 that placed over 4 million cubic meters of sand on the eastern $7.5 \mathrm{~km}$ of Perdido Key and an additional 3 million cubic meters in an offshore bar (6 meters water depth). A program that monitored the stability of the nourishment revealed that after eight years Perdido Key had maintained $56 \%$ of the original 4.1 million cubic meters that was placed on the beach, and the beach was an average of $53 \mathrm{~m}$ wider than pre-nourishment (Browder and Dean, 2000). Figure 11 shows how the sand from the 1989 nourishment project impacted the results of our shoreline change calculation. The long term effects of beach nourishment on mitigating erosion are unknown.

Cultural resources at GUIS can be used to illustrate the difference in coastal dynamics from the Mississippi islands to Florida. Civil War-era Fort Massachusetts is located on West Ship Island in Mississippi. The bay shoreline fronting this fort has been experiencing severe erosion which has led 
to a number of management and renourishment projects to preserve this historic cultural resource (fig. 12). Conversely, Fort Pickens was built only 150 yards from the bay in 1834, however spit progradation on Santa Rosa has resulted in accretion in front of the fort.

\section{Conclusions}

The coastal vulnerability index (CVI) provides insight into the relative potential of coastal change due to future sea-level rise. The maps and data presented here can be viewed in at least two ways:

1) to identify areas where physical changes are most likely to occur as sea-level rises; and

2) as a planning tool for managing and protecting resources in the Gulf Islands National Seashore.

As ranked in this study, regional coastal slope and shoreline change are the most important variables in determining the CVI for GUIS. Wave height, tide range, and geomorphology produce little to no variability in the coastal vulnerability index. GUIS preserves a dynamic natural environment, which must be understood in order to be managed properly.

\section{References}

Browder, A.E., and Dean, R.G., 2000, Monitoring and comparison to predictive models of the Perdido Key beach nourishment project, Florida, USA: Coastal Engineering, v. 39, no. 2-4, p. 173-191.

Douglas, B.C., 1997, Global sea rise; a redetermination: Surveys in Geophysics, v. 18, p. 279-292.

Doyle, L., Dinesh, C., Hine, A., Pilkey, O. Jr., Neal, W., Pilkey, O. Sr., Martin, D., Belknap, D., 1984, Living with the West Florida Shore: Duke University Press, Durham, North Carolina, $222 \mathrm{p}$.

Gornitz, V. and White, T.W. 1992, A coastal hazards database for the U.S. West Coast: ORNL/CDIAC-81, NDP-043C. Oak Ridge National Laboratory, Oak Ridge, Tennessee.

Gornitz, V.M., Daniels, R.C., White, T.W., and Birdwell, K.R., 1994, The development of a coastal vulnerability assessment database, Vulnerability to sea-level rise in the U.S. southeast: Journal of Coastal Research, Special Issue No. 12, p. 327-338.

Hammar-Klose, E.S., and Thieler, E.R., 2001, Coastal Vulnerability to Sea-Level Rise, A Preliminary Database for the U.S. Atlantic, Pacific, and Gulf of Mexico Coasts: U.S. Geological Survey, Digital Data Series, DDS-68, 1 CD-ROM.

Hubertz, J.M., Thompson, E.F., and Wang, H.V., 1996, Wave Information Studies of U.S. coastlines, Annotated bibliography on coastal and ocean data assimilation: WIS Report 36, U.S. Army Engineer Waterways Experiment Station, Vicksburg, 31 p. 
IPCC, 2001. Climate Change 2001, The Scientific Basis; Contribution of Working Group I to the Third Assessment Report of the Intergovernmental Panel on Climate Change: IPCC, Geneva, Switzerland, 563 p. Also available on the web at http: www.ipcc.ch.

National Research Council, 1990, Managing Coastal Erosion, Washington: National Academy Press, 163 p.

National Research Council, 1995, Beach Nourishment and Protection, Washington: National Academy Press, 334 p.

Pilkey, O.H., and Davis, T.W., 1987, An analysis of coastal recession models, North Carolina coast, in D. Nummedal, O.H. Pilkey and J.D. Howard, eds., Sea-level Fluctuation and Coastal Evolution: SEPM (Society for Sedimentary Geology) Special Publications No. 41, Tulsa, Oklahoma, p. 59-68.

Shaw, J., Taylor, R.B., Forbes, D.L., Ruz, M.H., and Solomon, S., 1998, Sensitivity of the Canadian Coast to Sea-Level Rise: Geological Survey of Canada Bulletin 505, 114 p.

Thieler, E.R., and Hammar-Klose, E.S., 1999, National Assessment of Coastal Vulnerability to Sea-Level Rise, U.S. Atlantic Coast: U.S. Geological Survey Open-File Report 99-593, 1 sheet.

Thieler, E.R., and Hammar-Klose, E.S., 2000a, National Assessment of Coastal Vulnerability to Sea-Level Rise, U.S. Pacific Coast: U.S. Geological Survey Open-File Report 00-178, 1 sheet.

Thieler, E.R., and Hammar-Klose, E.S., 2000b, National Assessment of Coastal Vulnerability to Sea-Level Rise, U.S. Gulf of Mexico Coast: U.S. Geological Survey Open-File Report 00-179, 1 sheet.

Zervas, C., 2001, Sea Level Variations of the United States 1854-1999: NOAA Technical Report NOS CO-OPS 36, 201 p 


\section{FIGURES}

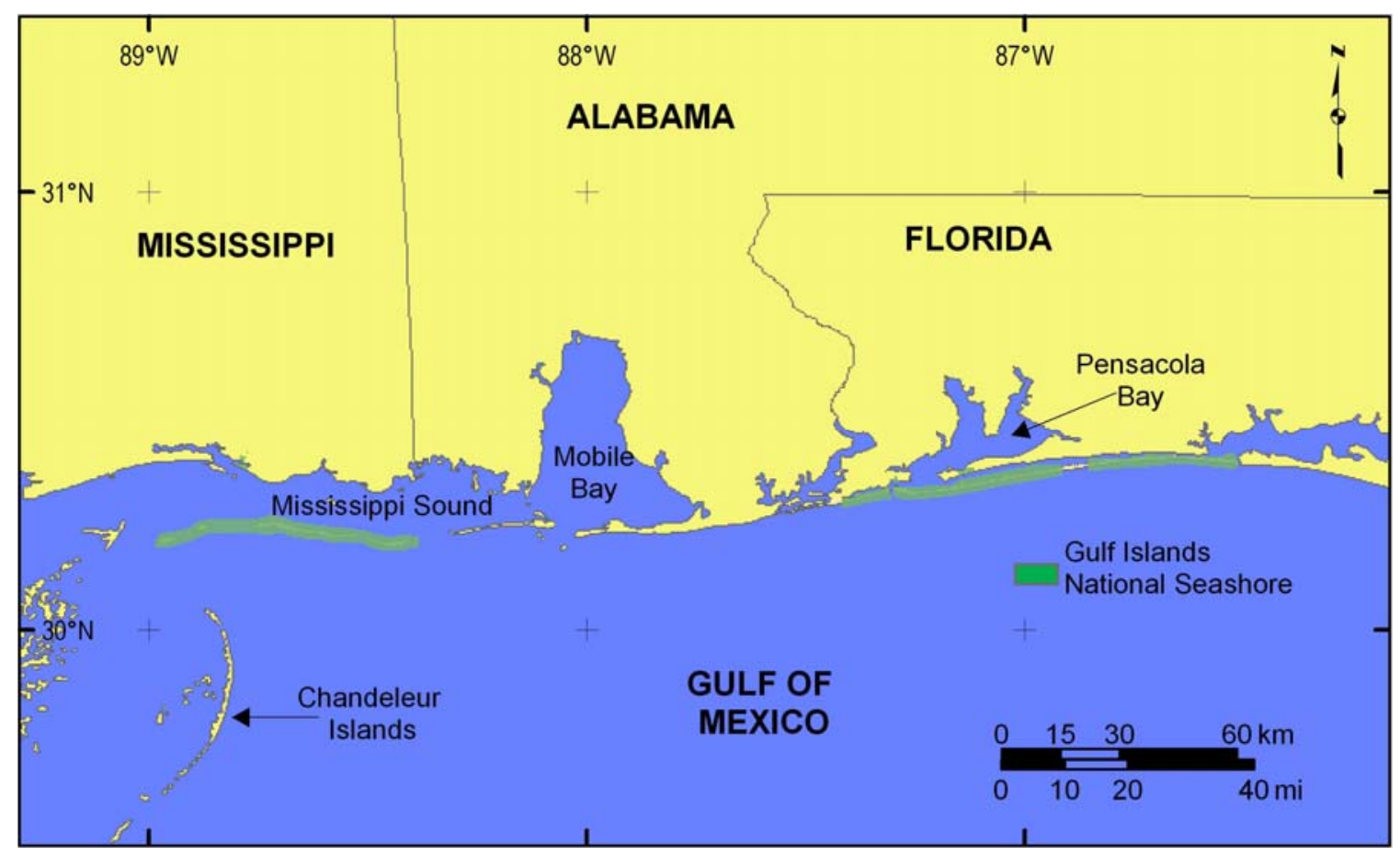

Figure 1. Location of Gulf Islands National Seashore. A) Gulf Islands of Mississippi. B) Gulf Islands of Florida.

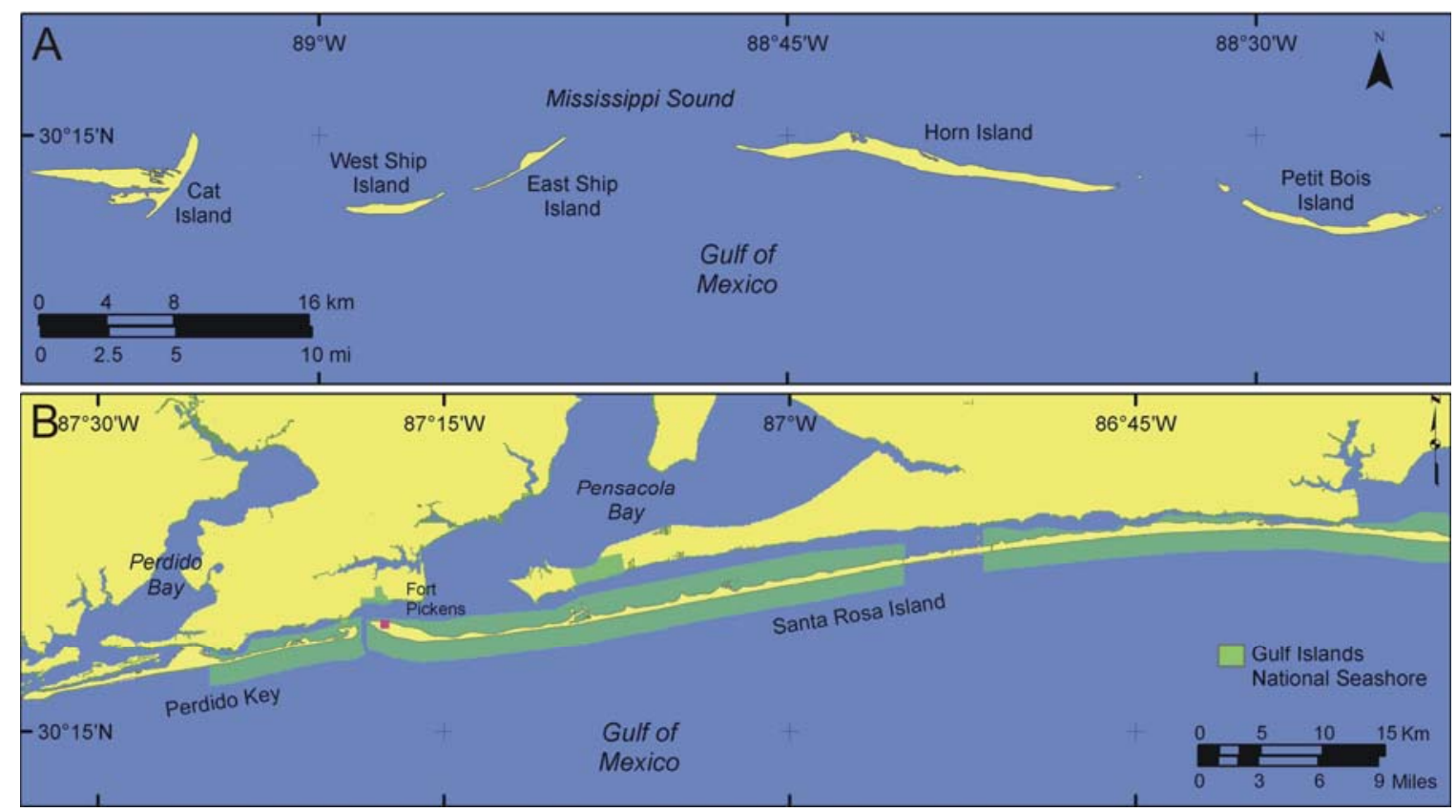




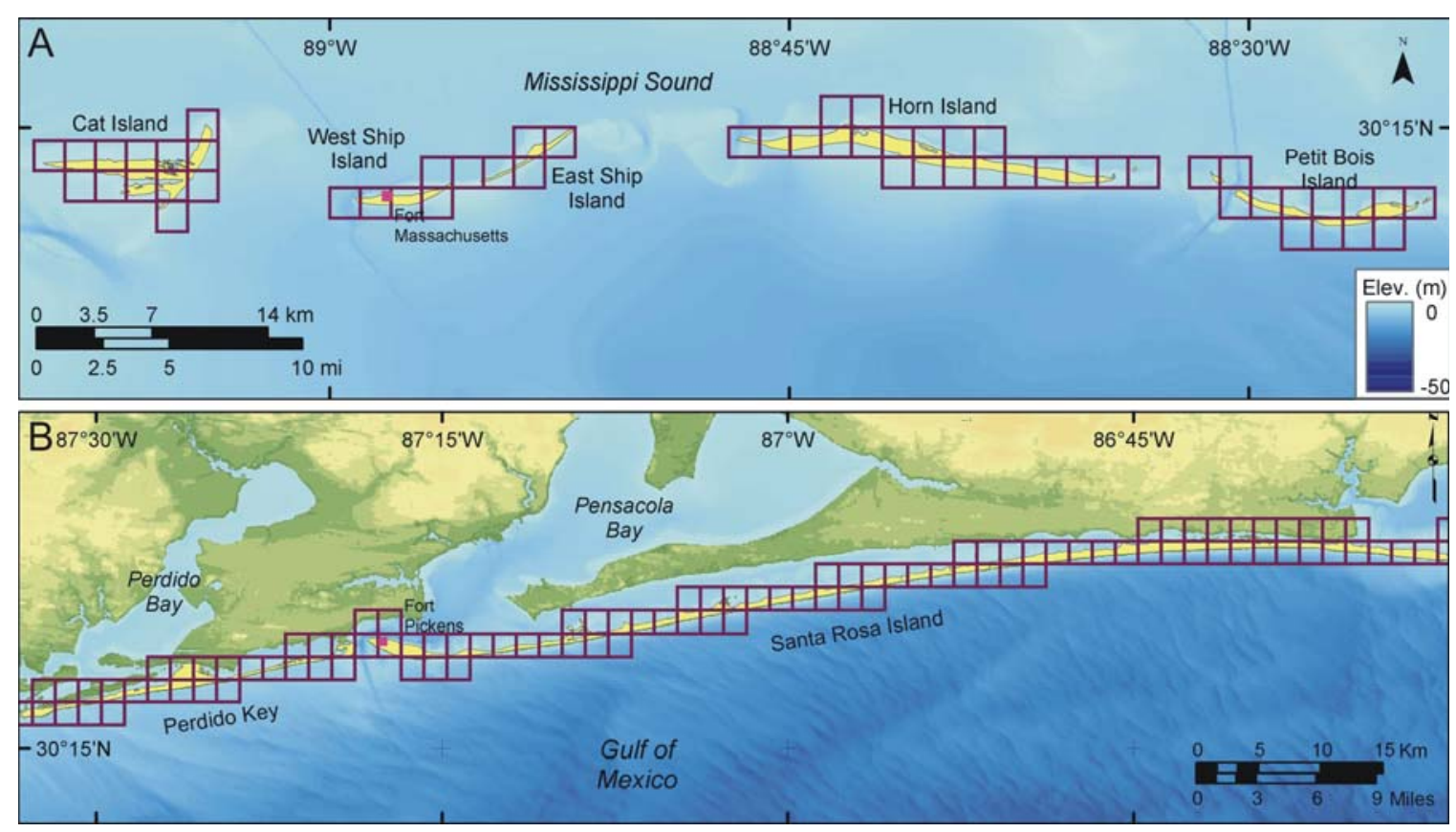

Figure 2. A) Shoreline grid for Mississippi Islands. B) Shoreline grid for Florida islands.

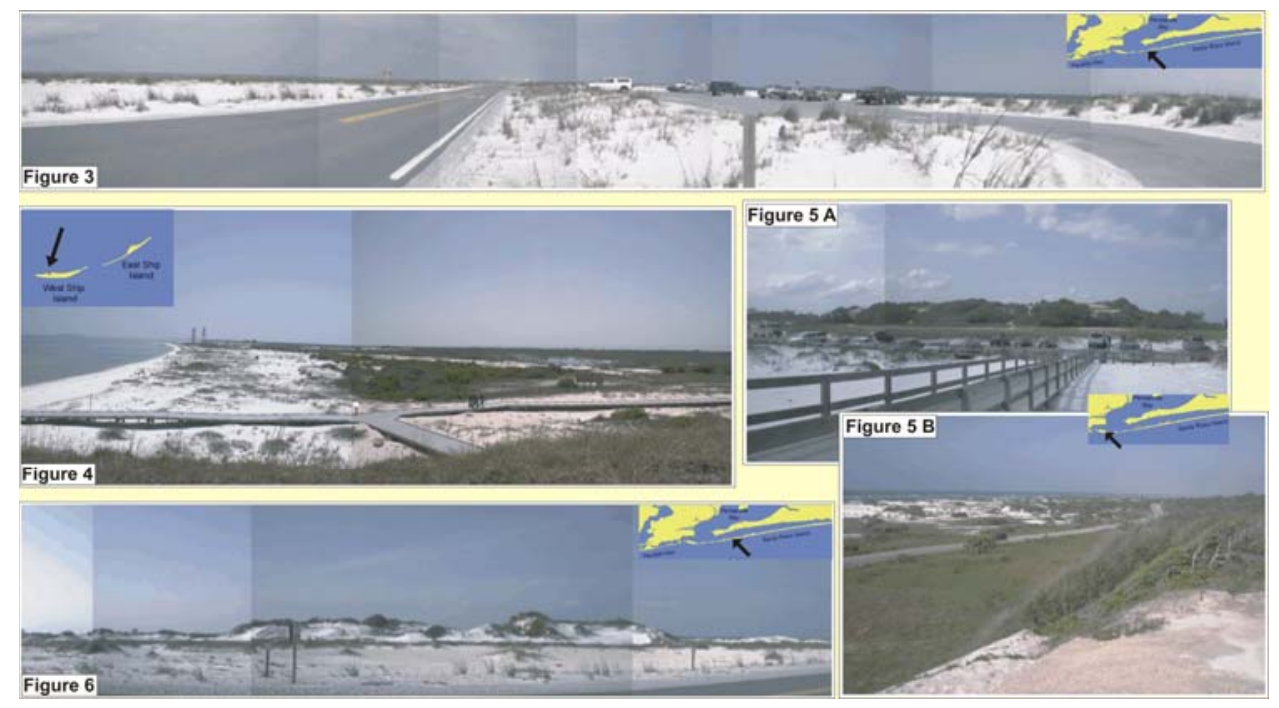

Figure 3. Dominant geomorphology of Santa Rosa Island (5-very high vulnerability), here elevation is low from the Gulf (right) to Pensacola Bay (left).

Figure 4. West Ship Island looking east from Civil War era Fort Massachusetts. The geomorphology is characterized as a low elevation overwashed barrier island (5- very high vulnerability).

Figure 5. A) Langdon Battery near Fort Pickens appears to set on top of a large dune, however the elevation is artificial from old gun emplacements. B) view from the top of Langdon Battery. 
Figure 6. Dune ridge (4- high vulnerability) adjacent to washover (5- very high vulnerability) on Santa Rosa Island.

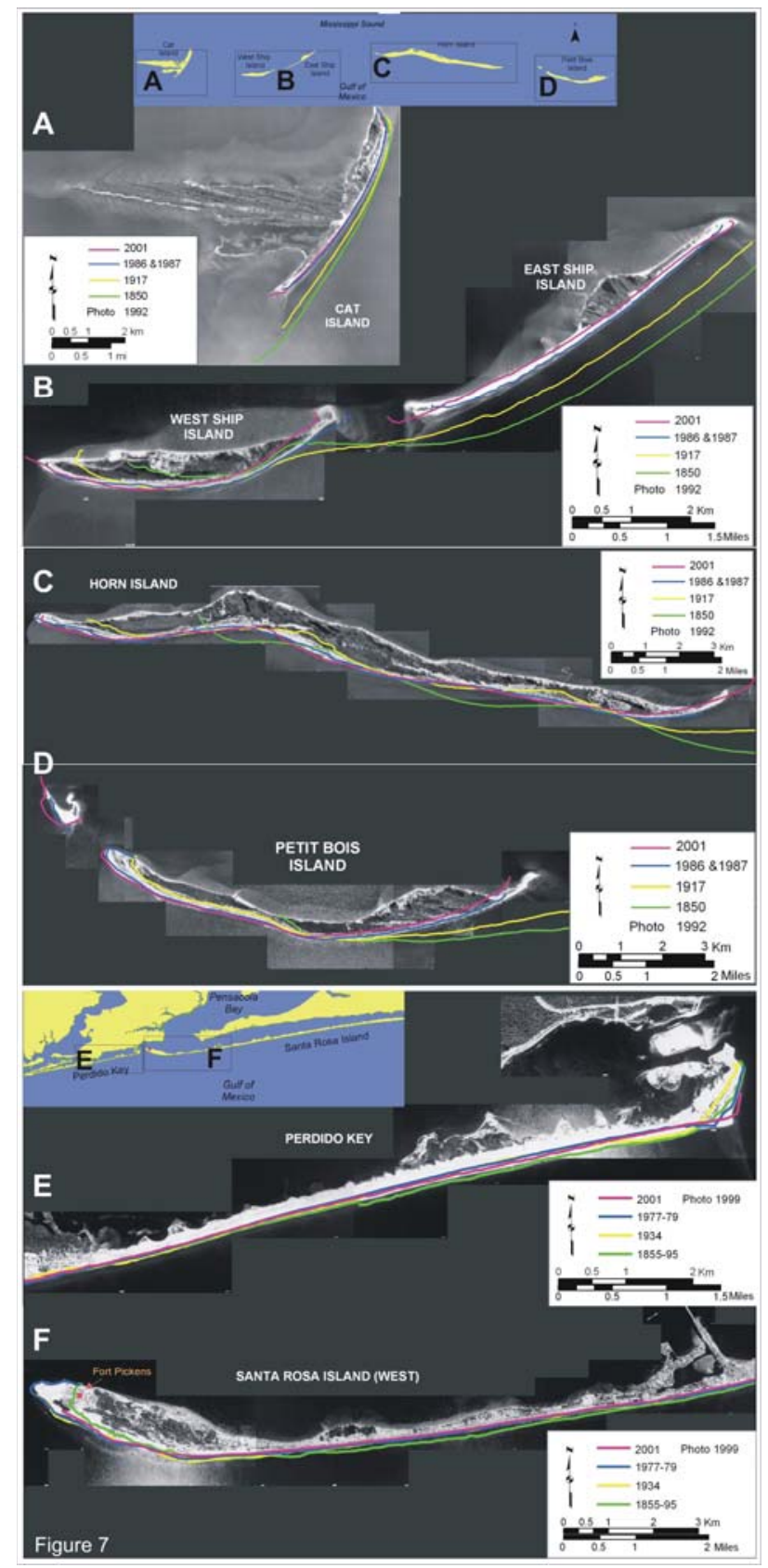

Figure 7. Historic Shoreline positions for A) Cat Island, B) East and West Ship Island, C) Horn Island, D) Petit Bois Island, E) Perdido Key, and E) Western Santa Rosa Island. 


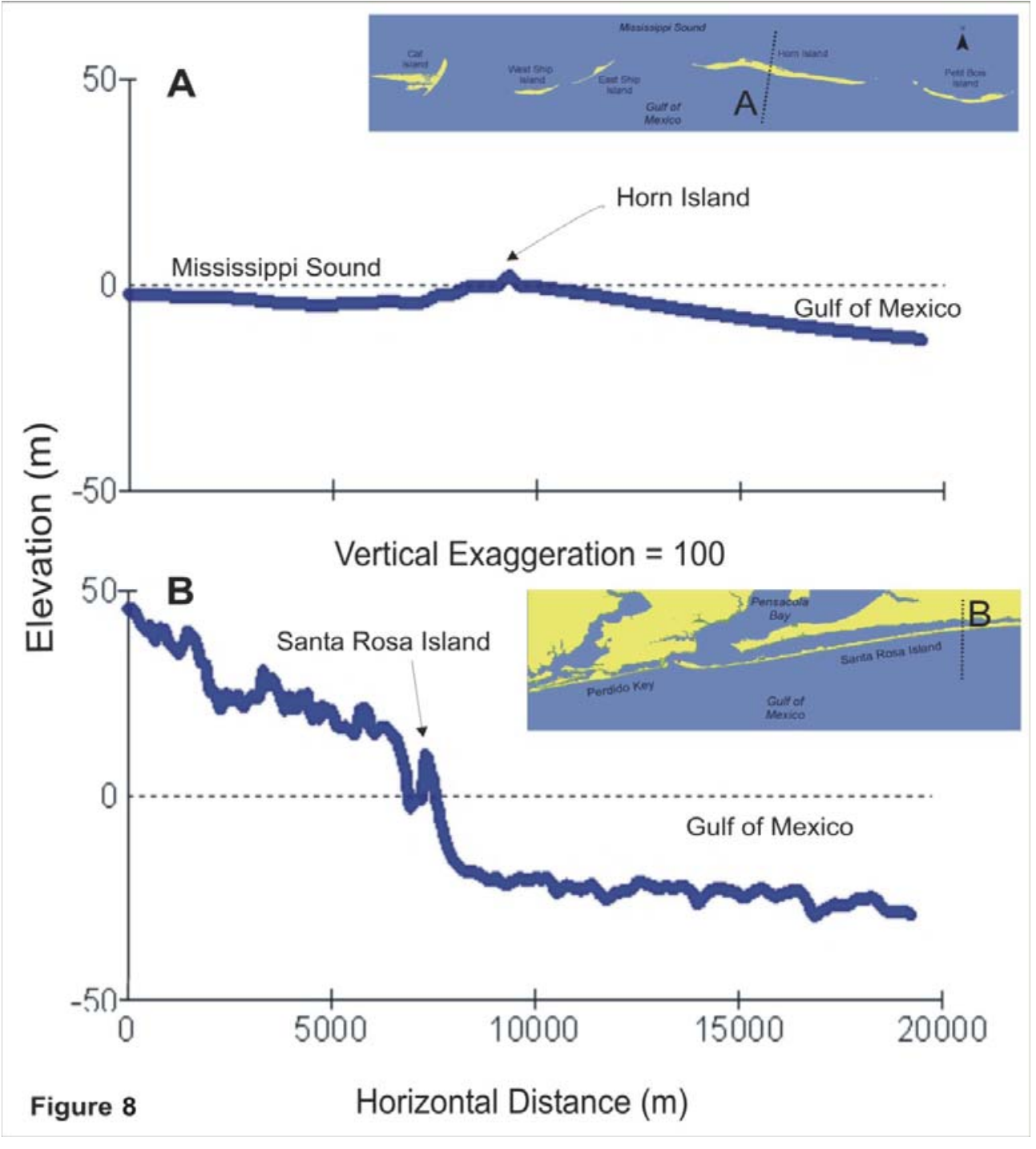

Figure 8. Regional coastal slope cross-section of A) Horn Island (5 - very high vulnerability). B) Santa Rosa Island (3 - moderate to 2 - low vulnerability). The low vulnerability portion of Santa Rosa is shown in the profile. 


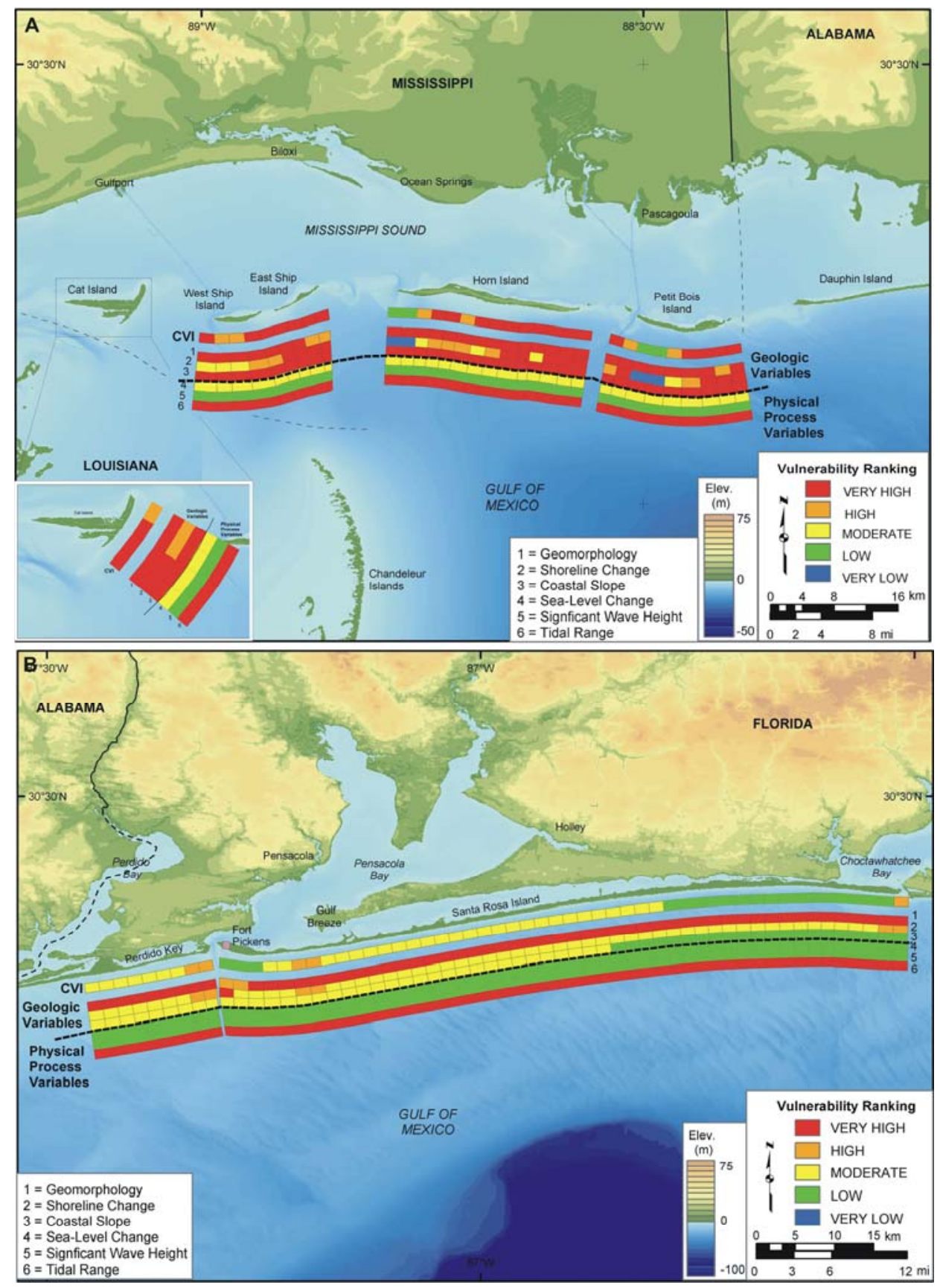

Figure 9. Relative Coastal Vulnerability for Gulf Islands National Seashore A) in Mississippi and B) in Florida. The innermost color bar is the relative coastal vulnerability index (CVI). The remaining color bars are separated into the geologic variables (1-3) and physical process variables (4-6). The very high vulnerability shoreline is generally along the eastern Mississippi islands. High vulnerability shoreline is concentrated around areas with a shoreline change rate between +/- 1-meter. Moderate vulnerability shoreline is primarily on Perdido Key and Santa Rosa Island, and the low vulnerability portion of the shore lies along the eastern end of Santa Rosa Island. 




Figure 10. Percentage of GUIS shoreline in each CVI vulnerability category. 


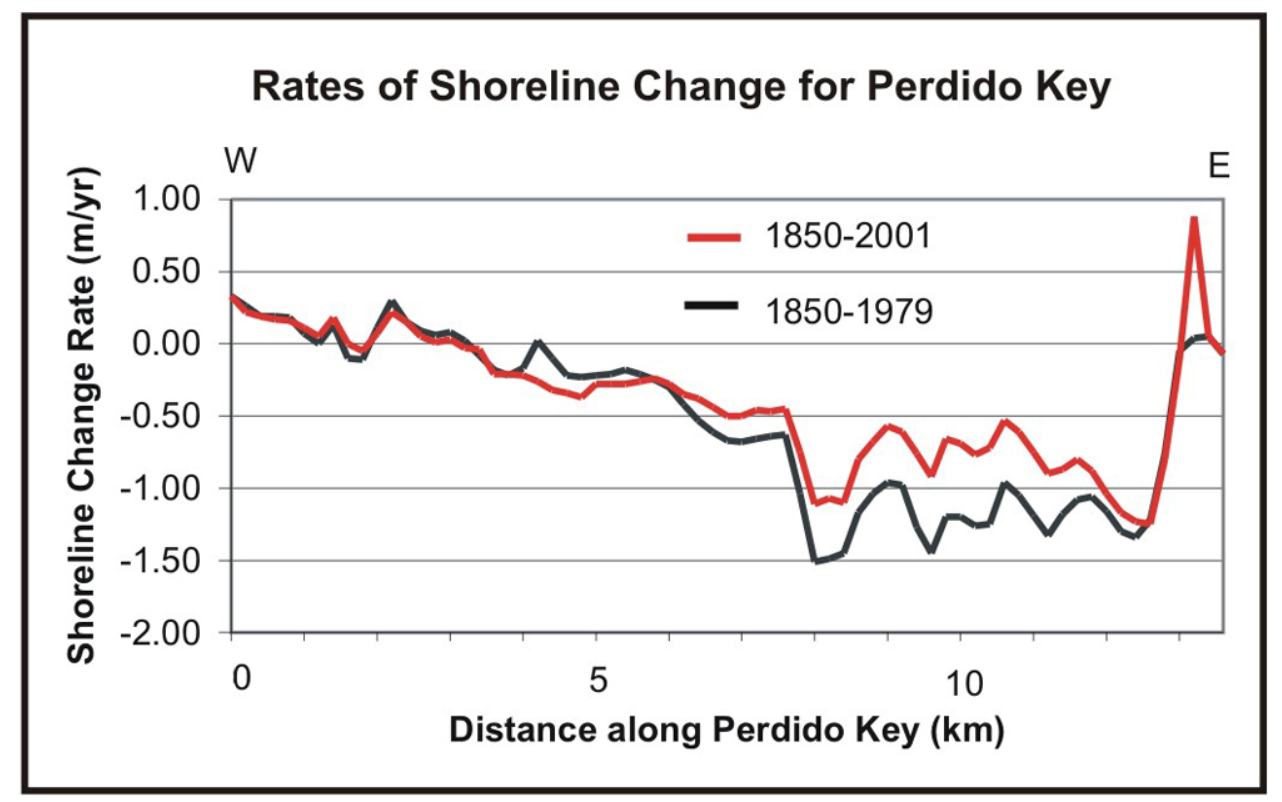

Figure 11. 4.1 million cubic meters of nourishment sand were placed on Perdido Key in 1989 which influenced the rate of shoreline erosion. Prior to 1989 (black line) the calculated rate of erosion on the eastern end of Perdido Key was approximately $0.5 \mathrm{~m} / \mathrm{yr}$ greater than after 1989 (red line). 


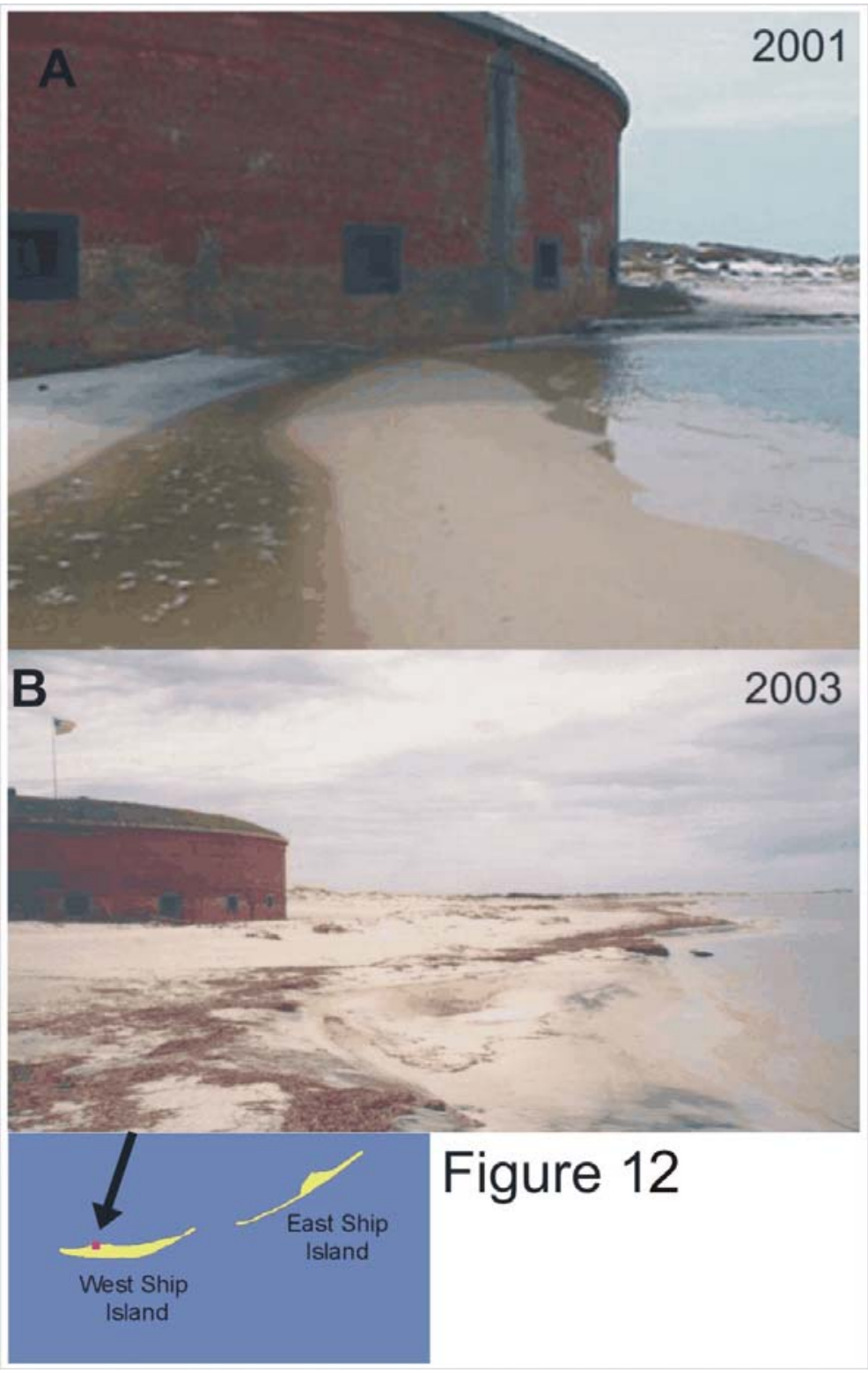

Figure 12. A) Ft. Massachusetts in 2001 before renourishment. B) Ft. Massachusetts in fall 2003 following beach renourishment in the spring (photos provided by Linda York). 


\section{TABLES}

Table 1. Ranges for Vulnerability Ranking of Variables on the Atlantic Coast.

\begin{tabular}{|c|c|c|c|c|c|}
\hline Variables & $\begin{array}{c}\text { Very Low } \\
1\end{array}$ & $\begin{array}{l}\text { Low } \\
2\end{array}$ & $\begin{array}{c}\text { Moderate } \\
3\end{array}$ & $\begin{array}{l}\text { High } \\
4\end{array}$ & $\begin{array}{l}\text { Very High } \\
5\end{array}$ \\
\hline GEOMORPHOLOGY & $\begin{array}{l}\text { Rocky cliffed } \\
\text { coasts, Fjords }\end{array}$ & $\begin{array}{l}\text { Medium cliffs, } \\
\text { Indented coasts }\end{array}$ & $\begin{array}{l}\text { Low cliffs, } \\
\text { Glacial drift, } \\
\text { Alluvial plains }\end{array}$ & $\begin{array}{l}\text { Cobble Beaches, } \\
\text { Estuary, Lagoon }\end{array}$ & $\begin{array}{l}\text { Barrier beaches, Sand } \\
\text { beaches, Salt marsh, } \\
\text { Mud flats, Deltas, } \\
\text { Mangrove, Coral reefs }\end{array}$ \\
\hline $\begin{array}{c}\text { SHORELINE } \\
\text { EROSION/ACCRETION } \\
(\mathrm{m} / \mathrm{yr})\end{array}$ & $>2.0$ & $1.0-2.0$ & $-1.0-1.0$ & $-2.0--1.0$ & $<-2.0$ \\
\hline COASTAL SLOPE (\%) & $>1.20$ & $1.20-0.90$ & $0.90-0.60$ & $0.60-0.30$ & $<0.30$ \\
\hline $\begin{array}{l}\text { RELATIVE SEA- } \\
\text { LEVEL CHANGE } \\
(\mathrm{mm} / \mathrm{yr})\end{array}$ & $<1.8$ & $1.8-2.5$ & $2.5-3.0$ & $3.0-3.4$ & $>3.4$ \\
\hline $\begin{array}{c}\text { MEAN WAVE HEIGHT } \\
(\mathrm{m})\end{array}$ & $<0.55$ & $0.55-0.85$ & $0.85-1.05$ & $1.05-1.25$ & $>1.25$ \\
\hline $\begin{array}{l}\text { MEAN TIDE RANGE } \\
(\mathrm{m})\end{array}$ & $>6.0$ & $4.0-6.0$ & $2.0-4.0$ & $1.0-2.0$ & $<1.0$ \\
\hline
\end{tabular}




\section{Table 2. Sources for Variable Data}

\begin{tabular}{|c|c|c|}
\hline Variables & Source & URL \\
\hline GEOMORPHOLOGY & $\begin{array}{l}\text { Aerial Photography } \\
\text { from MassGIS }\end{array}$ & http://www.state.ma.us/mgis/ \\
\hline $\begin{array}{l}\text { SHORELINE } \\
\text { EROSION/ACCRETION (m/yr) }\end{array}$ & $\begin{array}{c}\text { USGS } \\
\text { Administrative } \\
\text { Report: The } \\
\text { Massachusetts } \\
\text { Shoreline Change } \\
\text { Project: 1800's - } \\
1994 \text { (Thieler et al., } \\
\text { 2001) }\end{array}$ & http://www.state.ma.us/czm/shorelinechange.htm \\
\hline COASTAL SLOPE (\%) & $\begin{array}{l}\text { NGDC Coastal } \\
\text { Relief Model Vol } \\
0112 / 17 / 1998\end{array}$ & http://www.ngdc.noaa.gov/mgg/coastal/coastal.htm/ \\
\hline $\begin{array}{l}\text { RELATIVE SEA-LEVEL } \\
\text { CHANGE }(\mathrm{mm} / \mathrm{yr})\end{array}$ & $\begin{array}{l}\text { NOAA Technical } \\
\text { Report NOS CO- } \\
\text { OPS } 36 \text { SEA } \\
\text { LEVEL } \\
\text { VARIATIONS OF } \\
\text { THE UNITED } \\
\text { STATES 1854- } \\
\text { 1999 (Zervas, } \\
\text { 2001) }\end{array}$ & $\begin{array}{l}\text { http://www.co- } \\
\text { ops.nos.noaa.gov/publications/techrpt36doc.pdf }\end{array}$ \\
\hline MEAN WAVE HEIGHT (m) & $\begin{array}{l}\text { North Atlantic } \\
\text { Region WIS Data } \\
\text { (Phase II) and } \\
\text { NOAA National } \\
\text { Data Buoy Center }\end{array}$ & $\begin{array}{l}\text { http://bigfoot.wes.army.mil/ } \\
\text { http://seaboard.ndbc.noaa.gov/ }\end{array}$ \\
\hline MEAN TIDE RANGE (m) & $\begin{array}{l}\text { NOAA/NOS CO- } \\
\text { OPS Historical } \\
\text { Water Level Station } \\
\text { Index }\end{array}$ & http://www.co-ops.nos.noaa.gov/usmap.html \\
\hline
\end{tabular}

